\title{
The Role of BMT KUBE Sejahtera 036 in Empowering Community Economy in Maccini Gusung, Makassar City, Indonesia
}

\author{
Dabdurrahman Mansyur ${ }^{*}$, (D) Nurul Hudaya ${ }^{2}$, \\ Engku Muhammad Tajuddin Engku Ali ${ }^{3}$ \\ 1,3Universiti Sultan Zainal Abidin, Malaysia \\ ${ }^{2}$ Universitas Islam Indonesia, Indonesia \\ *Corresponding Email: a.rahmansyur@gmail.com
}

Keywords:

BMT,Empowerment, Community Economy.
Kata Kunci:

BMT, Pemberdayaan, Ekonomi Masyarakat.
Article Information Issue Hou To Cite

\section{ABSTRACT}

BMT KUBE Sejahtera 036 as an Islamic microfinance institution has not only economic functions but also social functions, which is empowering the community's economy. This study aims to determine the role as well as the supporting and inhibiting factors of BMT KUBE Sejahtera 036 in empowering the community's economy in Maccini Gusung. The research method used is a qualitative method with data analysis techniques from Miles and Hubberman which consists of reduction, data presentation, and conclusion. The results showed that BMT KUBE Sejahtera 036 played a role in empowering the community's economy through increasing customer income, enhancing the entrepreneurial spirit of the surrounding community through training and improving skills as well as providing the capital needs of MSMEs. The supporting factors of BMT KUBE Sejahtera 036 in empowering the community's economy are the right market and good service quality. In addition, programs or policies for extending payment terms and eliminating fines also increase public interest in accessing financing through this BMT. While the inhibiting factors are the lack of promotion, the emergence of other financial institutions, the implementation of financing procedures is not optimal, and the limited amount of capital.

\section{ABSTRAK}

Peran BMT KUBE Sejahtera 036 dalam Pemberdayaan Ekonomi Masyarakat di Maccini Gusung, Kota Makassar, Indonesia. BMT KUBE Sejahtera 036 sebagai lembaga keuangan mikro syariah tidak hanya memiliki fungsi ekonomi tetapi juga fungsi sosial yaitu pemberdayaan ekonomi masyarakat. Penelitian ini bertujuan untuk mengetahui peran serta faktor pendukung dan penghambat BMT KUBE Sejahtera 036 dalam memberdayakan ekonomi masyarakat di Kel. Maccini Gusung. Metode penelitian yang digunakan adalah metode kualitatif dengan teknik analisis data dari Miles dan Hubberman dengan melakukan proses reduksi, penyajian, dan penarikan kesimpulan. Hasil penelitian menunjukkan bahwa BMT KUBE Sejahtera 036 berperan dalam pemberdayaan ekonomi masyarakat melalui peningkatkan pendapatan nasabah, meningkatkan jiwa kewirausahaan masyarakat sekitar melalui pelatihan dan peningkatan keterampilan serta pemberian kebutuhan permodalan UMKM. Adapun faktor pendukung BMT KUBE Sejahtera 036 dalam pemberdayaan ekonomi masyarakat adalah, pasar yang tepat dan kualitas pelayanan yang baik. Selain itu, program atau kebijakan perpanjangan jangka waktu pembayaran dan penghapusan denda juga meningkatkan minat masyarakat untuk mengakses pembiayaan melalui $B M T$ ini. Sedangkan faktor penghambatnya adalah kurangnya promosi, munculnya lembaga keuangan lain yang serupa, pelaksanaan prosedur pembiayaan yang belum optimal, dan jumlah modal yang terbatas. 


\section{INTRODUCTION}

Poverty is one of the fundamental problems faced by the government in any country. Diah Retnowati defines poverty as a condition in which a person cannot enjoy all kinds of choices and opportunities in fulfilling their basic needs, such as foods, education, and health services (Retnowati \& Harsuti, 2016). Poverty does not only occur in rural areas but also in urban areas. The splendor of skyscrapers areas does not guarantee the welfare of the residents. The reality is, apart from skyscrapers, we also find many slum houses lined up on the outskirts of the city (Saidy \& Hidayah, 2018).

South Sulawesi, with a population of 8.82 million people, or equivalent to $46.4 \%$ of the total population of Sulawesi, continues to experience a decline in poverty rates. The number of poor people in South Sulawesi in March 2019 was 767.80 thousand people, a decrease of 24.83 thousand people compared to the same period in the previous year, which was 792.63 thousand people (Badan Pusat Statistik, 2019).

Among the cities in South Sulawesi, Makassar is a capital city that also experiences urban poverty problems. Urbanization is one of the causes of the increasing number of poor people in urban areas (Saidy \& Hidayah, 2018). The sparkling infrastructure development invites newcomers who hope to make a living in the capital (CNN Indonesia, 2019). Residents from rural areas come without adequate skills to get decent work that will affect the low income they receive. This explanation showed that many factors cause poverty. Nevertheless, movements aimed at eradicating poverty are also continuously carried out by the government, such as assistance provided to meet the needs of the people, creating jobs, and capital assistance (Saidy \& Hidayah, 2018) to empower the community's economy.

The problem of poverty engulfs the community due to their powerlessness in accessing information or abilities related to the economic aspect, therefore community economic empowerment is considered the main point in alleviating this poverty problem (Bagus, 2017). Thus, the role of Islamic financial institutions such as Islamic Banks and Islamic People's Financing Banks as Islamic financial institutions that collect and distribute funds must be able to achieve the goal of Islamic economics itself, namely to provide benefits. Unfortunately, the existence of these two types of financial institutions has not been able to eradicate poverty. So that poverty caused by lack of access to capital is still emerging. Therefore, a micro-savings and loan institution called Baitul Maal Wattamwil (BMT) was formed (Bagus, 2017).

One of the BMTs in Makassar City that performs the function of customer empowerment is BMT KUBE Sejahtera 036. This BMT has a vision of realizing BMT Kube Sejahtera Unit 036 as a strong, friendly, and reliable Islamic financial institution in empowering the people's economy, especially in helping the poor develop business in Maccini Gusung Village, Makassar City.

Research on BMT KUBE 036 has been done before by Muslihati in 2015. The research concluded that BMT KUBE 036 has an indirect role in empowering female members in the form of financial management. Although there is no specific program in BMT that handles women's economic empowerment. However, women's empowerment included in the vision and mission of BMT. As for the efforts of BMT in empowering the women's economy, namely monitoring the progress of the business of women financing participants periodically and holding regular recitations every week as a means of gathering BMT with its members.

A similar study was also conducted by Nurhidayah Ramdhani in 2017 on "Management of Qardhul Hasan Loans at BMT KUBE 036 Makassar" which concluded that in distributing qardhul hasan funds, BMT KUBE 036 only distributed it to its members, this is because the purpose of the qardhul hasan financing product is to help members improve welfare and empower the economy, after all qardhul hasan funds are taken from members' 
infaq funds.

However, when the researcher did the pre-study. Researchers found new facts. Mrs. Asriani who is a teller of BMT KUBE 036 stated in an interview that "currently the dominant contract is financing with a murabahah contract, which is consumptive financing for the purchase of electronic goods". This is certainly opposite to the vision of BMT KUBE 036 which focuses on assisting to the poor in empowering the economy through increasing business in Maccini Village, Makassar City. Based on previous research and the results of initial observations, the researcher found a research gap and was interested in further research related to "The Role of BMT KUBE Sejahtera 036 in Empowering Customers' Economy in Maccini Gusung Village, Makassar City".

Based on the background of the study, the research questions are :

1. What is the role of BMT KUBE Sejahtera 036 in empowering the economy of customers in Maccini Gusung Village, Makassar City?

2. What are the driving and inhibiting factors for the role of BMT KUBE Sejahtera 036 in empowering the economy of customers in Maccini Gusung Village, Makassar City?

\section{LITERATUR REVIEW}

\section{Mashlahah Concept}

The concept of maslahah was first raised by Imam Maliki, the founder of the Maliki mazhab, with the full term masalih al-mursalah or istihsan by other scholars (Amiruddin, 2015). Linguistically, maslahah comes from the word صط with the addition of "alif" at the beginning which means "good" as opposed to "bad". The word mashlahah is the masdar form of صلاح which is benefit or regardless of damage. As quoted by Rahmad Syafi'i in the book Lisanul Arabic that al-mashlahah is also a singular form (mufrad) of al-mashalih (صانخ ان). Everything means that there are benefits, either originally or through a process, such as producing pleasure and benefits, or prevention and care, such as avoiding harm and disease (Qorib \& Isnaini, 2016).

According to the term, mașlahah is bringing about all forms of benefit or rejecting all destructive possibilities. Benefit is an expression of the overall enjoyment obtained from the effort that has been made and everything that is still related to the benefit, while damage is the overall result that is harmful and painful or everything that has to do with the damage (Fahlefi, 2015). The Muslim scholar Imam Al-Ghazali was the first to formulate the concept of the social welfare function (maslahah). In his book Ihya Ulumuddin Al-Ghazali suggests that there are 5 aspects that influence the achievement of social welfare, namely; The main objectives of Islamic law are religion (din), soul (nafs), mind (aql), descendants (nasl), and treasure (maal).

Al-Ghazali also discusses the hierarchy of utility of a Muslim into 3 levels, namely:

1. Primary needs or dharuriyat, the purpose of this mașlahah is the fulfillment of basic needs, if these needs are not fulfilled it will endanger the life of person (Salma, 2012). In this case the five things that need to be maintained (maqa'idul khamsah) to achieve social welfare, including the primary needs of a Muslim.

2. The need for hajiyaat, which means the fulfillment of secondary needs (Karim, 2015), if this cannot be fulfilled it will not harm the person, but will cause difficulties for him (Sadat, 2013).

3. Tahsiniyat, is a complementary need for humans, this need is only complementary, if it cannot be fulfilled it will not harm or make difficulty for humans (Salma, 2012). 
According to Imam al-Ghazali, economic activity is part of the social obligations of society that have been determined by Allah SWT, if this is not fulfilled, the life of the world will collapse and human life will perish. Furthermore, Al-Ghazali formulated three reasons why someone should carry out economic activity; First to fulfill the needs of life, Second; welfare of the family, and thirdly helping others in need (Karim, 2015). Of the three criteria, it proves that a person's welfare will be fulfilled if their level of needs is fulfilled. Welfare at the theoretical level has many dimensions of application, but in this case it is more focused on the fulfillment of a person's welfare based on the level of need in terms of property.

\section{Baitul Maal at-Tamwil}

Baitul maal wattamwil is a microfinance institution that operates based on sharia principles (Soemitra, 2009) using a combination of the concepts of "baitul maal" and "baitul tamwil" whose operational targets focus on the Small and Medium Enterprises (SME) sector as well as the lower class community (Rusby, 2016). BMT as the name implies consists of two main functions, namely:

1. Baitul tamwil (house for property development), acts as a financial institution that seeks profit by carrying out productive business development activities and investment in improving the economic quality of micro and small entrepreneurs by encouraging saving and supporting the financing of productive economic activities (Rusby, 2016).

2. Baitul maal (house of treasure). Receiving deposits of zakat, infaq and alms funds and optimizing their distribution following the regulations and mandates (Soemitra, 2009).

The purpose of establishing Baitul Maal Wattamwil is to improve the quality of economic business for the welfare of members in particular and society in general. This can be understood that BMT is oriented towards efforts to improve the welfare of members and the community (Ridwan, 2005). The community and micro and small entrepreneurs are the main focus of BMT to improve their standard of living to be more prosperous and independent. Then another role is to provide loans or capital to micro and small entrepreneurs and accompany them, therefore they can gradually develop into medium entrepreneurs (Muljadi, 2017).

BMT also has several functions, including:

1. Keep people away from non-Islamic economic practices. Actively conduct socialization in the community about the importance of the Islamic system through training on Islamic ways of transacting so that there is evidence in transactions, prohibited from cheating in weighing goods, being honest with consumers, and so on.

2. Conducting coaching and funding small businesses. BMTs must be active in carrying out their functions as microfinance institutions, for example by mentoring, coaching, counseling, and supervising customers' businesses (Saifuddin, 2018).

3. Letting go of dependence on moneylenders. People are still dependent on money lenders because money lenders could fulfill people's desires of funds immediately. So BMT must be able to serve the community better, for example, always available funds at all times, simple bureaucracy, and so on.

4. Maintain community economic justice with an even distribution (Huda \& Heykal, 2010).

According to Slamet Mujiono (S. Mujiono, 2017), BMT identity is implemented into several main characteristics or main identities of BMT, namely:

1. As an institution based on sharia principles, whose activities are entirely subject to the principles and rules of the sharia game;

2. As a Micro Finance Institution which is the driving force for the micro and small business sector (UMK). With a focus on distribution to the MSE sector, which is the lifeblood of 
the majority of the Indonesian people, it is hoped that the productivity of the community as a whole will increase;

3. As a Maal Institution related to the Maal function in BMT activities. The function of the mall is as a tool for empowering the poor with certain schemes that are not based on business or financial calculations;

4. As an Indonesian Cooperative. BMT is also a microfinance institution in Indonesia that has focused on serving the financial needs of MSEs from the start.

\section{Community Economic of Empowerment}

The term empowerment has become a trend and has become a conversation (discourse) in the last two decades. There are various perspectives put forward by several experts and organizations in understanding the meaning of empowerment (Lubis, 2016). In terms of language, it comes from the word "daya" which means strength or ability to do business (Mustangin et al., 2017). According to Sumodiningrat, community empowerment is an effort to make the community independent by its potential capabilities. Community empowerment always involves two interrelated groups, namely the community as the empowered party and the concerned party as the empowering party (Yasin, 2015).

From various views on the definition of community empowerment, it can be concluded in general that community empowerment is an effort to restore or improve the ability of a community to be able to following their dignity in carrying out their rights and responsibilities as members of the community. With empowerment, it is hoped that the community will have a proactive culture for mutual progress, know themselves and their environment and have a responsible attitude and position themselves as subjects in development efforts in their environment (Mubarak, 2010).

\section{Community Empowerment Indicators}

Concerning the development of empowerment indicators, Schuler, Hashemi and Riley developed eight empowerment indicators which they call the empowerment index (Muljono et al., 2019), namely: (a) Freedom of mobility, (b) Ability to buy inexpensive commodities, (c) Ability to buy expensive commodities, (d) Involvement in household decisions, (e) Relative freedom from family domination, (f) Legal and political awareness, (g) Involvement in campaigns and protests, (g) Economic security and family contributions.

\section{Dimensions of Community Empowerment}

According to Jim Ife \& Frank Tesoriero (Ife \& Tesoriero, 2008), there are at least six dimensions of community development or empowerment and all of them interact with one another in complex forms. The six dimensions are:

1. Social development

2. Economic development

3. Political development

4. Cultural development

5. Environmental development

6. Personal/spiritual development 


\section{Empowerment in Islamic Perspective}

Empowerment is a very important aspect of muamalah because it is related to community development and change. In the Qur'an it is explained how important a change is, that change can be done in one way (Hendra, 2017), as mentioned in QS. Ar-Ra'd: 11:

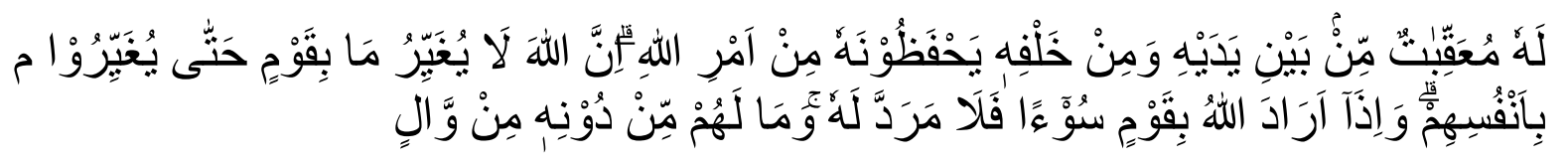

Translation :

"....Indeed, Allah will not change the condition of a people until they change what is in themselves. And when Allah intends for a people ill, there is no repelling it. And there is not for them besides Him any patron." (Q.S Ar-Ra'd : 11)

One of the reasons for empowerment is to eradicate poverty. It is often said that poverty is manifested due to a poor economic system, but in fact, there are many factors that influence this phenomenon, not only because of external factors such as lack of access to resources or a culture that does not support progress and prosperity, but it could also be due to internal factors such as lack of mental productive activities such as laziness and lack of motivation. Therefore, it is necessary for the people themselves to change their living conditions.

As in QS. Ar-Rad verse 11, Islam also teaches Muslims to live independently. From this verse, Allah certainly states that humans have to strive to make changes in their lives, including getting out of the trap of poverty. Community empowerment is an effort carried out in the form of activities that seek to make people aware so that they can use their potential to achieve a better standard of living in all aspects (Hendra, 2017).

Poverty in the view of Islam is neither a punishment nor a curse from God. However, this is due to the wrong human understanding of the distribution of income. Islam through the Qur'an has explained that there are many steps in empowering the community, including the principle of ta'awun or help. This is alluded to in QS. Az-Zukhruf verse 32:

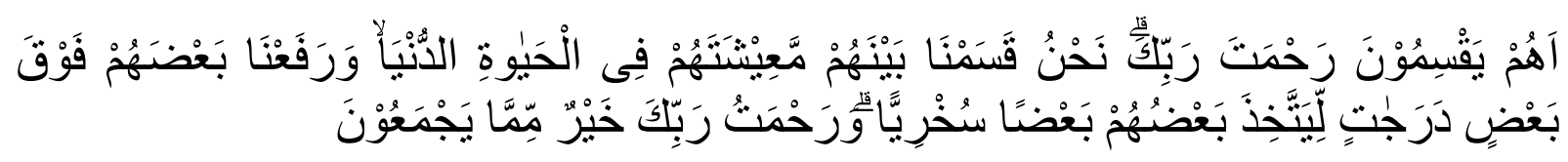

Translation :

"Do they distribute the mercy of your Lord? It is We who have apportioned among them their livelihood in the life of this world and have raised some of them above others in degrees [of rank] that they may make use of one another for service. But the mercy of your Lord is better than whatever they accumulate” (QS. Az-Zukhruf : 32)

Quraish Shihab in Tafsir Al-Misbah (Shihab, 2005) explains the ayat Az-Zukhruf verse 32 that Allah has divided humans in this life because they cannot do it alone and Allah has exalted some of them in property, knowledge, strength, and so on for some others so that they can help each other in fulfilling their needs. Each of them needs each other in finding and managing their lives (Gusfitri, 2014).

The verse shows that poverty is mostly caused by the wrong attitude and behavior of the people in understanding the verses of Allah Almighty especially the understanding of 
property ownership (Setiadi, 2019). Excessive hoarding of wealth, and any assets that are limited in circulation to the rich only, and prohibiting it against the poor are not accepted by Islam. However, rich people should spend and distribute their wealth to fellow human beings and give their rights to the poor as realize an even distribution in enjoying God's grace (Hidayat, 2017).

Thus, absolute poverty in sociological theory does not happen if Muslims understand correctly and thoroughly the verses of God. Islam is essentially a religion that teaches and encourages its believer to achieve the wealth of life both materially and spiritually. Zakat and Hajj as two of the five pillars of Islam reflect this aspect. The implementation of these two pillars of Islam requires the existence of material wealth or adequacy. If the implementation of Hajj and zakat requires material sufficiency, then achieving that adequacy becomes obligatory. In other words, the pillars of Islam oblige its ummah to be materially well off (Setiadi, 2019). Therefore, getting out of the poverty trap through empowerment is a way of implementing the 5 pillars of Islam.

\section{RESEARCH METHOD}

This research is qualitative study. Qualitative research is a study that intends to understand the phenomenon of what is experienced by research subjects such as behavior, perception, motivation, action, and language in a special natural context and by utilizing various natural methods (Tohiri, 2013).

The analysis technique used follows the concept of Miles and Huberman which consists of three stages, namely:

1. Data Reduction. The essence of data reduction is combining and uniforming all forms of information obtained into one written form to be analyzed (Herdiansyah, 2012). The author reduces all the information obtained by summarizing, selecting essential data, then categorizing the data according to the research focus. The reduced data provides a more in-depth picture of the role of BMT KUBE Sejahtera 036 in empowering the community's economy in Kel. Maccini, Makassar City.

2. Data Display. After the evidence is reduced, then the following step is to present the data. In qualitative research, presentation can be done in the form of brief descriptions, charts, relationships between categories. This will make it easier for the writer to understand what happened and plan further work based on what has been understood.

3. Conclusion/Verification. The third step in analyzing the data is drawing conclusions and verification (Sugiyono, 2011). All the evidence that has been collected then proceed to be reexamined. So that the results of research or the description of an object under study becomes clearer.

The types of data that can be obtained based on the source are primary and secondary evidence. The primary dossier was obtained and collected directly by conducting interviews with the management and members of BMT KUBE Sejahtera Unit 036. While secondary goods were obtained from written sources such as books, scientific papers, statistical data, and websites that can provide information about BMT.

Informants in this study include:

1. Management of BMT KUBE Sejahtera Unit 036 : Manager and Teller.

2. Customers of BMT KUBE Sejahtera 036 : Six constumers. 


\section{RESULT AND DISUCSSION}

\section{Result}

\section{Overview of BMT KUBE Sejahtera 036}

BMT KUBE Sejahtera 036 established on 3 December 2004, to be exact on Friday at Jalan Maccini Sawah no.80 Maccini Gusung Village, Makassar City. The vision of BMT KUBE Sejahtera 036 is to realize BMT KUBE Prosperous Unit 036 as a strong, friendly, and reliable Islamic financial institution in empowering the people's economy, especially in helping the poor in increasing business in Maccini Gusung Village and Makassar City in particular and South Sulawesi in general. While the mission of this BMT is:

1. Inviting people to deposit some of their funds in BMT with a sense of security and mutual trust.

2. Providing sharia financing to members to improve the quality of worship and participate in the economic empowerment of the people

3. Conduct business coaching and consulting to strengthen and grow the business

4. Conducting faith development and Islamic insight, especially in the realization of sharia economics.

\section{The Role of BMT KUBE Sejahtera 036 in Empowering Community Economy}

The establishment of BMT KUBE Sejahtera 036 aims to improve the quality of economic business for the welfare of members and the public. Based on the results of the interviews, the six respondents have various types of businesses. As seen in Table 1.1 below

Table 1: Member and Type of Business of BMT KUBE Sejahtera 036

\begin{tabular}{|c|c|}
\hline Name of Member & Types of Business \\
\hline Idris & Building Material \\
\hline Muliana & LPG Gas Distributor \\
\hline Hafsyah & Clothes and Clothing Screen Printing \\
\hline Rahmawaty & Grocery Store \\
\hline Ramlah & Street Vendors \\
\hline Hasni & Street Vendors \\
\hline
\end{tabular}

Source : Results of interviews with respondents

The role of BMT KUBE Sejahtera 036 in empowering the customer's economy includes 3 things, including:

\section{Increase Income}

Empowerment is giving the community the chance to improve their dignity and become self-sufficient. For this reason, BMT KUBE Sejahtera 036 focuses on providing financing as a form of customer economic empowerment, expectantly that customers will be able to develop their business and increase their income. Several informants, when asked about their income level after obtaining BMT financing gave the same answer. According to Mr. Idris as the recipient of financing at BMT KUBE Sejahtera 036, he said that: 
"I have been taking financing at BMT for 5 years. I took two loans. One was 1 year and the other was 6 years. Alhamdulillah. My income has increased, because from there (BMT) I get capital. From there I also developed it. Now my income increased more than 2 million rupiah."

A similar statement was also conveyed by Mrs. Muliana as a mudharabah financing customer at BMT KUBE Sejahtera 036 she said that:

"I became a member in 2005. I took profit-sharing financing and sold LPG later the results were divided by 50:50. Alhamdulillah, I can meet my daily needs. Now it's decreasing because sometimes the gas delivery does not come. My income from LPG sales is around 480 thousand, after dividing two with BMT."

Based on the result, the researchers concluded that BMT KUBE Sejahtera 036 has played a role in empowering the customer's economy. The results of this study are similar to the results of (Lubis, 2016) and (Vijayanti, 2016) that concluded that empowerment is successful if there is an increase in customer income compared to the situation before becoming a BMT customer.

\section{Developing an Entrepreneurial Spirit Through Training}

BMT KUBE Sejahtera 036 in improving the ability of customers and the community was used to collaborate with PLUT-KUMKM (Center for Integrated Cooperatives and Micro, Small and Medium Enterprises) Makassar City. When PLUT conducts training, the BMT will be contacted to prepare its members who want to take part in the training. The types of training are different every year such as how to process patchwork, screen print clothes, make quality handicrafts, sew, and so on. Following the results of an interview with the Manager of BMT KUBE 036, Mrs. Nurhidayanti, she said that:

"Yes, here we also have training for members. We collaborate with PLUT so that every time they hold training we will be contacted. Then, we contact members who want to take part in the training and help the to join it. There is patchwork training, screen printing, sewing. It was once held at UNHAS, if I'm not mistaken it was an overnight stay, so we also accompanied the members who participated until the activity was over."

One of the members of BMT KUBE Sejahtera 036, Mrs. Muliana, admitted that she had attended one of the entrepreneurship training she said:

"I have participated in the training at UNHAS, by Mrs. Yanti, right? Mrs. Yanti accompanied me. I make handicrafts, but that's all. After that, I never came again, because I was constrained by work"

The same opinion was also expressed by Mrs. Hafsyah, who said she had attended the training:

"Yes, I have participated in a clothing screen printing training, from there I started to open a screen printing business, borrowed the funds from BMT. 


\section{Thank God until now my business is continuing."}

The main objective of the training, namely to form individuals or customers who are economically independent, then in line with the results of the interviews of the informants, efforts to empower customers' economy through skills training are quite successful. This is shown by the business of Mrs. Hafsyah established after attending a shirt screen printing training. However, this activity, unfortunately, cannot be followed by all customers. The training is prioritized for former members of BMT KUBE Sejahtera 036, according to what the Teller of BMT KUBE Sejahtera 036, Mrs. Asriani, said:

"That training is prioritized for old members who registered when the new $B M T$ was formed. That's why the new ones didn't participate. For a long time there was no training in PLUT since 2 years ago."

This expression indicates a decrease in the role of empowering BMT KUBE Sejahtera 036 due to the decrease in the intensity of cooperation between PLUT and BMT KUBE Sejahtera 036. It is unfortunate if skills training is no longer carried out because training is one of the factors that affect one's entrepreneurial interest. According to human capital theory, investment in knowledge, skills and abilities increases an individual's productivity. This is also supported by the results of Elsa Ardhilya Falaly (Falaly \& Ilyas, 2016) that found skills training affects youth entrepreneurship interest in Gunungsari Village, Pemalang Regency, which is indicated by the increase in the entrepreneurship enthusiast after attending training..

Based on the description of the interview results, despite the decrease of skills training activity, the researcher concluded that BMT KUBE Sejahtera 036 has a role in empowering the customer's economy through training because 0there are still customers who start businesses after participating in the training.

\section{Fulfill Capital Needs}

One aspect of the problems faced by the underprivileged community is capital (Harahap, 2012). Therefore, microfinance institutions such as BMT KUBE Sejahtera 036 play influential role in this part to meet the capital needs of business actors through financing. The customer uses the financing received from BMT KUBE Sejahtera 036 as additional capital and fulfills the needs related to his business. The contracts used to meet the customer's capital needs are murabahah, mudharabah and rahn contracts. Following the results of an interview with Mr. Idris as a customer of murabahah financing, he said:

"I took a loan for business capital, namely buying and selling materials. I used to have little capital, so I borrowed from BMT for my business. And now I borrow to enlarge my business. You can see on the outside, I bought all of that from a BMT loan."

This opinion was also confirmed by Mrs. Rahmawaty as a customer of BMT KUBE Sejahtera 036 she said:

"I borrowed Rp. 2.000.000 from BMT, the payment period was 1 year. I borrowed it to be used as business capital. Thank God I can develop my business. I prefer BMT because there are no fines than other financial institutions like Bank" 
The interview show the role of BMT KUBE Sejahtera 036 in increasing the economic empowerment of customers through fulfilling capital needs. However, this function continues to decline each years as shown in Table 2.

Table 2: Number of KUBE Prosperous BMT Financing Members 036

\begin{tabular}{|c|c|c|c|}
\hline \multirow{2}{*}{$\begin{array}{c}\text { Types of } \\
\text { Financing }\end{array}$} & \multicolumn{3}{|c|}{ Number of Member } \\
\cline { 2 - 4 } & $\mathbf{2 0 1 7}$ & $\mathbf{2 0 1 8}$ & $\mathbf{2 0 1 9}$ \\
\hline Murabahah & 87 & 65 & 33 \\
\hline Mudharabah & 5 & - & - \\
\hline Qardhul Hasan & 34 & 3 & 3 \\
\hline Rahn & 24 & 9 & 2 \\
\hline Total & $\mathbf{1 5 0}$ & $\mathbf{7 7}$ & $\mathbf{3 8}$ \\
\hline
\end{tabular}

Source : Processed Data of BMT KUBE Prosperous 036

If interpreted, the table shows a decrease in the amount of financing at BMT KUBE Sejahtera 036 generally in all contracts. The magnitude of the decline is approaching 50\% every year, and murabahah contracts dominate the amount of financing. According to Mrs. Asriani (Teller), murabahah financing is the most sought after by customers, and the majority of the allocation objectives are consumptive.

"Nowadays, customers prefer Murabaha. Maybe it's because their needs are different, like buying electronics, cellphones, refrigerators, cupboards, and laptops. While financing for business purposes is quite rare. Qardhul hasan is also rare. Qardul Hasan's funds are obtained from the infaq of new members, while new members are also decreasing. Qardhul hasan usually intended for customers who cannot pay for medical expenses or given to underprivileged communities such as paying for children school."

Mrs. Asriani's expression shows that the number of productive financing for BMT KUBE Sejahtera 036 is decreasing that impacts the economic empowerment of BMT customers. Research from (Ayuliani, 2017), stated that additional working capital in the form of assistance or loans has a positive impact on business performance support this finding. Additional capital can stimulate efforts that improve business performance, such as additional equipment, additional workforce, and product innovation.

Supporting and Inhibiting Factors of Economic Empowerment BMT KUBE 036

The inhibiting factors of BMT KUBE Sejahtera 036 in empowering the customer's economy, namely: 


\section{Lack of Promotion}

Products or services of Islamic financial institutions in Indonesia, in general, have gone through various kinds of promotions through the media of pamphlets, advertisements, bulletins to participating in exhibitions about Islamic financial institutions (Faiqoh, 2013). However, it is different with product marketing at BMT KUBE Sejahtera 036. In accordance with the results of an interview with Mrs. Asriani as Teller of BMT KUBE Sejahtera 036 she said that:

"We have never done socialization anymore if there was at the beginning of the formation of this BMT."

The results of the interview show that the range of promotions of BMT KUBE Sejahtera 036 is limited to word of mouth (WOM). Meanwhile according to the results of research conducted by Herwan Eko Saputro (Saputro, 2017), stated that promotions have a vital effect on increasing the number of BMT's members but at BMT KUBE 036 only use a simple form of promotion so that the range of promotion is limited.

\section{The emergence of Financial Institutions that Offer Similar Financing}

There are now many financial institutions that offer to finance to the public. Moreover, these financial institutions provide fewer requirements than BMT KUBE. Following the results of an interview with Mrs. Nurhidayanti, she said that:

"Nowadays, there are many financial institutions that offer to finance like Hasamitra. It doesn't care what the purpose of the funds borrowed by customers is. While this BMT has procedure when applying for funds, we must know the reason because of sharia principles, while the community wants us as administrators not to know what the funds are used for."

Based on the description of the interview results, the researcher concludes that the results of this study are in line with the results of research conducted by Muhammad Zainuddin (Zainuddin, 2015), which stated that the external factors that caused the decline in the number of financing members at BMT were caused by the increasing number of competitors from financial institutions in the vicinity.

3. The Implementation of The Feasibility Analysis of Financing is Not Optimal

This problem is caused by the lack of prudential principles in the distribution of financing funds which causes high non-performing loans. Bad credit or also called NonPerforming Finance (NPF) is related to the customer's ability to repay the loan. To prevent these problems, BMT KUBE Sejahtera 036 applies SOPs for submission and supervision in the distribution of financing, but in practice, there are deviations from these procedures. In accordance with the results of the interview with Mrs. Asriani as the Teller of BMT KUBE Sejahtera 036, she said:

"In terms of an administration process, we have a survey mechanism in the SOP but, we are indeed the less competent. What's more, if we already know the person borrowing, the survey is fast even though we should have surveyed the 
house, collateral, etc. Now, this is what usually makes bad credit, so many have problems. Some of them disappeared even though the loan had not even been paid in half, the phone could not be contacted, and the address changed too."

The negligence of the BMT manager in the business feasibility analysis not only impacted the number of customers who are slow to make payments but also the customer's dishonesty in the transparency of business results.

Based on the description of the interview results, the researcher concludes that the results of this study have similarities with the research conducted by Agus Mujiono (A. Mujiono, 2016), which states that the implication of the precautionary principle that is not optimal will harm the internal or business of the institution as well as it's the reputation.

\section{Limited Amount of Capital}

Until now, the source of capital for BMT KUBE Sejahtera 036 still comes from their funds. The limited capital of BMT resulted in the presence of financing included in the feasible category but could not be realized. This was mentioned by Mrs. Nurhidayanti as the Manager of BMT KUBE Sejahtera 036, who stated that:

"Our main problem is capital. There was once a customer who used to accept our financing, but at that time, he wanted 20 million rupiahs, and we didn't have much capital at that time, so we had to refuse."

This expression shows that limited capital is one of the factors that hinder BMT KUBE Sejahtera 036 in empowering the customer's economy. The results of this study are correlated with Multisari Fatra research (Fatra et al., 2015) which states that capital and management development are factors that affect the performance of cooperatives.

Meanwhile, the supporting factors for BMT KUBE Sejahtera 036 in empowering the community's economy include :

\section{Extend Payment Times and Eliminating Fines Policy}

The emergence of non-performing financing is caused by various factors, one of which is caused by the decrease in the level of customer income so that the ability to pay also decreases. To overcome the risk of problematic financing due to default, BMT KUBE Sejahtera 036 made several efforts in the form of rescheduling and the elimination of fines. Rescheduling or changing the payment schedule for the obligations of BMT KUBE Sejahtera 036 customers is carried out by referring to the DSN-MUI fatwa No. 48 of 2005, namely rescheduling can be done but does not add to the remaining bill because it will cause usury and an extension of the payment period must be based on the agreement of both parties (DSN MUI, 2005). The community is greatly helped by this regulation because some customers get uncertain profits from their business according to what was said by one of the informants, namely Mrs. Ramlah as a customer of BMT KUBE Sejahtera 036, she said:

"I borrowed money from BMT to buy a laptop for my son. The price is 4.5 million with 40x installments per week. Because my husband's income decreased, so it was changed to $80 x$ installments. Thank God, because BMT can understand my condition, I can add more time to pay." 
Another policy that eases customer payments is the elimination of late payment penalties. Based on the DSN-MUI fatwa No. 17 of 2000 (DSN MUI, 2000), customers who can pay but do not have the will and good faith to pay their debts may be subject to sanctions and customers who have not been able to pay due to force majeure may not be penalized (Endang \& Yusuf, 2017). However, BMT KUBE Sejahtera 036 chose to abolish the imposition of fines on all financing. This policy considerably eased the burden on people who had not been able to make payments under the results of an interview with Mrs. Ramlah as the recipient of the murabahah financing. She said :

"Alhamdulillah, there is no fine for late payments, usually Mr Iqbal, who comes here collects. The distance is not too far."

The same opinion was also expressed by Mrs. Hasni as a customer of BMT stated that :

"I have been a member of the BMT for a long time, many times have I been late in paying, and there are no fines that Iqbal asked for. That's the difference with the bank because if you pass one day at the bank, you immediately pay a fine."

Based on the description of the results of the interviews from the two informants, the researcher concluded that the ease in the payment process was one of the supporting factors for BMT KUBE Sejahtera 036 because the community felt helped by the rescheduling policy and the abolition of fines.

\section{The Right Market}

BMT KUBE Sejahtera 036 operates in Maccini Gusung Village, Makassar City where there are many people who make a living as a MSEs owner. The customer's business will be better with additional capital from financing that could get quickly. Following the results of an interview with Mr. Idris as a customer of BMT KUBE Sejahtera 036, he said:

"Well, thank God, since I borrowed from BMT, my income has increased, and my business has survived until now. I have been a member of BMT for 5 years."

Based on the outcome, the researcher concludes that the proper market share is a supporting factor for BMT KUBE Sejahtera 036 in empowering the customer's economy. It can be understood that the selection of market share will determine the institution's productivity, where BMT KUBE Sejahtera 036 provides micro-financing worth Rp. 300.000 up to millions of rupiah.

\section{Good Service Quality}

The services provided by BMT KUBE Sejahtera 036 are polite in serving customers, responsive to customer problems and pick-up service or payment if customers have problems to come to offices. Under the results of an interview with Mrs. Ramlah, she said:

"The BMT people are all friendly if the service isn't good, I won't be a member until now. If I can't go to the office to pay, the BMT management will come here to provide solutions to the problems I'm facing." 
Based on the description above, the researcher concluded that the quality of service was a supporting factor for BMT KUBE Sejahtera 036 in empowering the community's economy in Maccini Gusung Village. The results of this study are in line with the results of Wirdayani Wahab (Wahab, 2017) research, which concluded that Islamic Banking in Pekanbaru City has a satisfactory quality of service so that customers do not need to feel hesitant to become customers in Islamic Banking in Pekanbaru City.

\section{Discussion}

\section{Maslahah Theory and the Role of BMT KUBE Sejahtera 036}

The role of BMT KUBE Sejahtera 036 in empowering the community's economy in Maccini Gusung can be viewed from the Maqashid Syariah concept initiated by Al Ghazali, namely; religion (din), soul (nafs), mind (aql), descendants (nasl), and treasure (maal).

\section{Religion (din)}

The concept of maintaining religion in this study can be seen from how BMT Kube Sejahtera 036 refuses to use the usury system through a mulct mechanism. On the other hand, BMT KUBE Sejahtera 036 provides an extension of time for customers to make it easier for them to repay loans. On the other hand, concerning the increase in income described by $\mathrm{Mr}$. Idris and Mrs. Muliana. Customers who experience an increase in income can fulfill their fourth obligation as Muslims, namely Zakat.

\section{Soul (nafs)}

The maintenance of the souls of BMT KUBE Sejahtera 036 customers can be seen from the activities of BMT KUBE Sejahtera 036 through Qardhul Hasan financing obtained from new members Infaq. This charity fund is used to help customers who are in trouble, such as unable to pay for health costs.

\section{Mind (aql)}

The maintenance of mind in BMT KUBE Sejahtera 036 is by conducts entrepreneurial training for customers and the surrounding community by collaborating with PLUT-KUMKM (Center for Integrated Cooperatives and Micro, Small and Medium Enterprises) Makassar City. This entrepreneurship training aims to provide new knowledge for customers, so after going through the training, customers can open a business and get capital from BMT KUBE Sejahtera 036.

\section{Descendants (nasl)}

The maintenance of offspring (nasl) for customers of BMT KUBE Sejahtera 036 can be seen from the activities of BMT KUBE Sejahtera 036, which subsidizes school fees for children in the community around the Maccini Gusung area.

\section{Treasure (maal)}

The maintenance of Maal is closely related to increasing customer income and 
providing business capital. This can be seen from all the answers from respondents who revealed that BMT KUBE Sejahtera 036 had a crucial impact on economic development and people's lives in the Maccini Gusung area, Makassar City.

\section{CONCLUSION}

Based on the above discussion, it may be inferred that:

1. The role of BMT KUBE Sejahtera 036 in empowering the customer's economy includes increasing income, developing the customer's entrepreneurial spirit through skills training and fulfilling customer capital needs. Although the funding and training program held by the BMT KUBE Sejahtera 036 decreased. However, the program conducted by BMT KUBE Sejahtera 036 impact the surounding community to maintain their five aspect of Maqashid Sharia which are religion (din), soul (nafs), mind (aql), descendants (nasl), and treasure (maal).

2. The supporting factors of BMT KUBE Sejahtera 036 in empowering the customer's economy in Maccini Gusung are the policy of extending payment periods and eliminating fines, suitable market share, and good service quality. Meanwhile, the inhibiting factors of BMT KUBE Sejahtera in empowering the customer's economy include the limited range of promotions, the emergence of financial institutions that offer similar financing, not implemented financing procedures, and the limited amount of capital.

\section{REFERENCES}

Amiruddin, K. (2015). Nilai Maslahat dalam Sistem Ekonomi Islam. EcceS, 2(1).

Ayuliani, H. H. (2017). Dampak Pinjaman dan Bantuan Modal terhadap Kinerja Usaha. Jurnal Riset Ekonomi Dan Bisnis, 10(3).

Badan Pusat Statistik. (2019). Profil Kemiskinan di Indonesia, Maret 2019.

Bagus, A. D. (2017). Pemberdayaan Ekonomi Anggota Koperasi Jasa Keuangan Syariah Melalui Produk Pembiayaan Di Koperasi Simpan Pinjam Dan Pembiayaan Syariah Muamalah Berkah Sejahtera Surabaya. Jurnal Ekonomi Syariah Teori Dan Terapan, 4(8).

DSN MUI. (2000). DSN MUI No 17 Tahun 2000 Tentang Sanksi Nasabah Mampu yang Menundanunda Pembayaran (No. 17).

DSN MUI. (2005). DSN MUI No. 48 Tentang Penjadwalan Kembali Tagihan Murabahah (No. 48).

Endang, M., \& Yusuf, A. (2017). Analisis Penerapan Denda di Lembaga Keuangan Syariah Perspektif Hukum Islam. Jurnal Al-Amwal, 9(2), 311.

Fahlefi, R. (2015). Implementasi Maslahah dalam Kegiatan Ekonomi Syariah. Juris, 14(2), 226.

Faiqoh, R. (2013). Analisis Strategi Pemasaran KPRS di Bank Muamalat Cabang Kudus. IQTISHADIA Jurnal Kajian Ekonomi Dan Bisnis Islam, 6(2), 282.

Falaly, E. A., \& Ilyas. (2016). Pengaruh Pelatihan Keterampilan Sapu Glagah terhadap Minat Berwirausaha Pemuda Desa Gunungsari Kecamatan Pulosari. Journal of Noformal Education, 2(2), 148.

Fatra, M., Haryana, G., \& Caska. (2015). PENGARUH FAKTOR MODAL DAN PEMBINAAN 
MANAJEMEN TERHADAP KINERJA KOPERASI DI KOTA PEKANBARU. Jurnal Fakultas Keguruan Dan Ilmu Pendidikan, 2(1).

Gusfitri. (2014). Manajemen Pembelajaran Program Akselerasi Dalam Perspektif Pendi-dikan Islam Di SMP Negeri 2 Kota Solok. Jurnal Al-Fikra, 2(2), 128.

Harahap, E. F. (2012). Pemberdayaan Masyarakat dalam Bidang Ekonomi Untu-k Mewujudkan Ekonomi Nasional yang Tangguh dan Mandiri. Jurnal Manajemen Dan Kewirausahaan, $3(2), 88$.

Hendra, T. (2017). Pemberdayaan Masyarakat Dalam Perspektif al-Qur'an. Jurnal Hikmah, 11(2), 2.

Herdiansyah, H. (2012). Metodologi Penelitian Kualitatif untuk Ilmu-Ilmu Sosial. Salemba Humanika.

Hidayat, T. (2017). Konsep Pendistribusian Kekayaan Menurut Al-Qur'an. Jurnal Al-Falah, 2(1), 17.

Huda, N., \& Heykal, M. (2010). Lembaga Keuangan Islam Tinjauan Teoristis dan Praktis (K. P. M. Group (ed.)).

Ife, J., \& Tesoriero, F. (2008). Community development: alternatif pengembangan masyarakat di era globalisasi (S. Manurung, N. Yakin, \& M. Nusyahid (eds.)). Pustaka Pelajar.

Karim, A. (2015). Ekonomi Mikro Islam (1st ed.). Rajagrafindo Persada.

Lubis, F. A. (2016). Peranan BMT dalam Pemberdayaan Ekonomi Nasabah di Kecamatan BerastagiKabanjahe Kab. Karo. Human Falah, 3(2), 272.

Mubarak, Z. (2010). Evaluasi Pemberdayaan Masyarakat Ditinjau Dari Proses Pengembangan Kapasitas Pada Kegiatan PNPM Mandiri Perkotaan Di Desa Sastrodirjan Kabupaten Pekalongan. UNDIP.

Mujiono, A. (2016). Penerapan prinsip Kehatu-hatian dalam Pembiayaan dan Kredit di BMT Hasanah dan BRI Unit Mlarak, Ponorogo. Jurnal Muslim Heritage, l(1), 159.

Mujiono, S. (2017). Eksistensi Lembaga Keuangan Mikro: Cikal Bakal Lahirnya BMT di Indonesia. Jurnal Al-Musraf, 2(2), 213.

Muljadi, M. (2017). Prospek Baitul Maal Wattamwil (BMT) Dalam Memajukan Pengusaha Mikro. Dynamic Management

Journal. http://jurnal.umt.ac.id/index.php/dmj/article/viewFile/249/160

Muljono, P., Purwono, J., Cahyadi, E. R., \& Hamzah. (2019). Economical Empowerment Index of Posdaya as Participatory of Community Empowerment Programe in Indonesia. Italian Sociological Review, 9(1), 65-96.

Mustangin, Kusniawati, D., Islami, N. P., \& Setyaningrum, B. (2017). Pemberdayaan Masyarakat Berbasis Potensi Lokal Melalui Program Desa Wisata di Desa Bumiaji. Sosioglobal, 2(1), $59-72$.

Qorib, A., \& Isnaini. (2016). Penerapan Maslahah Mursalah dalam Ekonomi Islam. Analytica Islamica, $5(1), 55$.

Retnowati, D., \& Harsuti. (2016). Pengaruh Pengangguran terhadap Tingkat Kemiskinan di Jawa Tengah. Jurnal PKS, 15(2), 1. 
Ridwan, M. (2005). Manajemen Baitul Maal Wattamwil. UII Press.

Rusby, Z. (2016). Analisa Permasalahan Baitul Maal Wattamwil (BMT) melalui Pendekatan Analytical Network Process (ANP). Jurnal Al-Hikmah, 13(1), 19.

Sadat, A. (2013). Kedudukan Maslahah Perspektif Prof. K. H. Ali Yafie. Jurnal Al-Adl, 6(2), 30.

Saidy, E. N., \& Hidayah, N. (2018). Fenomena Kemiskinan di Kota Makassar dan Upaya Penanggulangannya dalam Perspektif Ekonomi Islam. Laa Maisyir, 5(1), 45.

Saifuddin, R. (2018). Integrations of Social and Profit Function of BMT in Lampung. Jurnal Kelitbangan Inovasi Dan Pembangunan, 4(3), 208.

Salma, S. (2012). Maslahah dalam Perspektif Hukum Islam. Jurnal Ilmiah Al-Syir'ah, 10(2).

Saputro, H. E. (2017). Pengaruh Promosi terhadap Peningkatan Jumlah Nasabah pada BMT Mentari Simbarwaringin. IAIN Metro.

Setiadi, D. (2019). Pemberdayaan Masyarakat Miskin Dalam Perspektif Teologi Pembangunan. UIN Raden Intan Lampung.

Shihab, M. Q. (2005). Tafsir Al-Misbah: Pesan, kesan dan keserasian Al-Qur'an (12th ed.). Lentera Hati.

Soemitra, A. (2009). Bank dan Lembaga Keuangan Syariah (Kencana (ed.)). Kencana.

Sugiyono. (2011). Metode Penelitian Kuantitatif Kualitatif Dan $R \& D$ (Alfabeta (ed.); 13th ed.).

Suyanto, B. (2001). Kemiskinan dan Pemberdayaan Masyarakat Miskin. Masyarakat, Kebudayaan Dan Politik, 14(4), 25-42.

Tohiri. (2013). Metode Penelitian Kualitatif dalam Pendidikan dan Bimbingan Konseling Pendekatan Praktis untuk Peneliti Pemula dan Dilengkapi Dengan Contoh Transkrip Hasil Wawancara serta Model Penyajian Data,. Rajawali Press.

Vijayanti, M. D. (2016). Pengaruh Lama Usaha Pedagang Sembako di Pasar Kumbasari. Jurnal Ekonomi Dan Pembangunan, 5(12).

Wahab, W. (2017). Pengaruh Kualitas Pelayanan terhadap kepuasan Nasabah Industri Perbankan Syariah di Kota Pekanbaru. Jurnal Maqdis, 2(1), 65.

Yasin, H. (2015). Upaya Strategis Pemberdayaan Ekonomi Masyarakat melalui Kelompok Usaha Bersama (KUBE). Jurnal Administrasi Publik, 5(1), 39.

Zainuddin, M. (2015). Analisis Penurunan Jumlah Nasabah pada Produk Pembiayaan Murabahah di BMT Surya Sekawan Mandiri. UIN Walisongo Semarang.

\section{Copyright Holder:}

(C) Mansyur, A., Hudaya, N., Tajuddin, M.E.M (2021)

Publication Right:

Talaa : Journal of Islamic Finance

Department of Sharia Financial Management IAIN Sultan Amai Gorontalo, Indonesia

(cc) BY-si 